\title{
KAJIAN POTENSI USAHA RENGGINANG SINGKONG
}

\author{
Nurul Latifah ${ }^{1)}$ dan Imam Juhari ${ }^{2}$ \\ Mahasiswa Fakultas Pertanian Universitas Wiraraja Sumenep; nurullatifah160898@gmail.com \\ Dinas Pertanian Tanaman Pangan, Hortikultura dan Perkebunan Sumenep
}

\begin{abstract}
Penelitian dilakukan di Desa Banasare Kecamatan Rubaru. Sejak tahun 2003 Desa Banasare mengolah singkong menjadi rengginang singkong, melalui industri rumah tangga "Produksi Moh. Sunaryo". Metode yang digunakan dalam penelitian ini menggunakan metode deskriptif kualitatif,. Strategi pengembangan Usaha dan indikator yang harus dicapai oleh Usaha Rengginang Singkong "Produksi Moh. Sunaryo". Potensi usaha dilihat berdasarkan ketersediaan bahan baku dan mutu rengginang singkong berdasarkan preferensi konsumen, rencana usaha masa mendatang dan tingkat keuntungan usaha rengginang. Hasil penelitian menunjukkan bahwa usaha rengginang singkong "Produksi Moh. Sunaryo" memiliki potensi yang baik untuk dikembangkan. Potensi tersebut dapat dilihat dari ketersediaan bahan baku melimpah dan lokasi bahan baku juga dekat dengan usah rengginang singkong selain itu kualitas produk dinilai baik berdasakan analisis preferensi konsumen.
\end{abstract}

Kata Kunci : Potensi, rengginang singkong, usaha

\section{A. PENDAHULUAN}

Rubaru merupakan sebuah kecamatan di Kabupaten Sumenep Madura. Kecamatan Rubaru termasuk salah satu daerah penghasil bermacam komoditas tanaman hasil pertanian baik itu tanaman pangan, holtikultura, dan perkebunan yang cukup besar di Kabupaten Sumenep. Selain itu, Kecamatan Rubaru memiliki potensi cukup banyak, mulai dari potensi wisata, pendidikan dan pertanian, sehingga dikenal dengan wilayah agropolitan (Samsul, 2018).

Banasare merupakan salah satu desa di Kecamatan Rubaru Kabupaten Sumenep. Di mana selain desa ini juga dikenal dengan daerah agropolitan dan sebagai sentra pasar tanaman pangan, holtikultura, dan perkebunan, Banasare juga memiliki potensi lahan pertanian yang subur sehingga mampu meningkatkan perekonomian masyarakat di desa tersebut. (Sugiman, 2018).

Luasan areal tanaman ubi kayu atau singkong Desa Banasare sekitar $6 \mathrm{Ha}$ dan mampu memproduksi singkong 90 ton/Ha dengan produktivitas 15 ton/Ha. Ubi kayu memiliki segmen pasar untuk lokal $75 \%$ dan di luar daerah $25 \%$. Hal ini menunjukkan bahwa ubi kayu atau singkong Desa Banasare sangat berpotensi untuk dikembangkan sebagai produk unggulan yang akan menuai keuntungan yang tinggi. Singkong bisa diversifikasi menjadi berbagai macam produk 
olahan yang dapat dijadikan sebagai produk unggulan berbasis bisnis Desa Banasare salah satunya rengginang singkong (Jayadi, 2018).

Sejak tahun 2003 Desa Banasare mengolah singkong menjadi rengginang singkong, di mana ada salah satu masyarakat yang mendirikan home industri kecil yakni Usaha Rengginang Singkong "Produksi Moh. Sunaryo", yang telah mengembangkan usahanya sampai saat ini meskipun sederhana.

Kurangnya SDM yang memadai mengakibatkan usaha tersebut tidak berjalan efektif dan efisien. Bahkan,proses pengolahan rengginang singkong masih secara tradisional (Yaya, 2018). Fenomena ini sangat menarik untuk dipelajari Karena Desa Banasare sudah memiliki potensi yang menarik untuk dikembangkan sebagai sebuah usaha besar yang nantinya akan menciptakan produk unggulan berupa rengginang singkong khas Banasare yang terkenal. Oleh karenanya sangat diperlukan kajian yang terkait dengan potensi usaha rengginang singkong Desa Banasare Kecamatan Rubaru Kabupaten Sumenep.

\section{METODE}

Metode yang digunakan dalam penelitian ini menggunakan metode deskriptif kualitatif. Secara deskriptif penelitian ini akan menggambarkan tentang potensi yang dimiliki oleh usaha rengginang singkong dengan menggunakan beberapa indikator capaian. Dikatakan kualitatif, karena penelitian ini tanpa adanya perhitungan atau angka. Adapun indikator yang digunakan yaitu :

1. Indikator ketersediaan bahan baku'

2. Indikator penggunakan teknologi

\section{Tempat dan Waktu}

Penelitian dilaksanakan industri rumah tangga "Produksi Moh. Sunaryo" di Desa Banasare Kecamatan Rubaru Kabupaten Sumenep. Penelitian dilakukan mulai Desember 2018 - Januari 2019.

\section{Tahapan Penelitian}

Penelitian dilakukan dengan tahapan sebagaimana berikut.

a. Penelitian pendahuluan. Penelitian pendahuluan dilakukan dengan survei dan wawancara terhadap pimpinan industri rumah tangga "Produksi Moh. Sunaryo.

b. Melakukan wawancara terkait ketersediaan bahan baku kepada pimpinan industri rumah tangga.

c. Observasi atau pengamatan potensi lahan pertanian yang memproduksi singkong di Desa Banasare.

d. Penyebaran kuesioner terhadap konsumen rengginang singkong.

e. Menganalisis data hasil penelitian.

\section{HASIL DAN PEMBAHASAN}

\section{Profil Usaha Rengginang Singkong "Produksi Moh Sunaryo"}

Usaha rengginang singkong "Produksi Moh. Sunaryo" ini sudah berjalan sekitar 15 tahunan sampai saat ini. Usaha ini beralamat di Dusun Banasare Timur RT 002 RW 002 Desa Banasare Kecamatan Rubaru Kabupaten Sumenep. Berdirinya usaha ini dipelopori oleh orang tua dari pemilik perusahaan yang pada awalnya hanya dalam rangka percobaan dengan inisiatif sendiri. Perusahaan ini sudah 
memiliki surat izin usaha atau SIUP. Dengan kode produksi : 503/48/SIUP. K/435/112/2012.

\section{Kekuatan Usaha Rengginang Singkong "Produksi Moh. Sunaryo"}

Berikut ini merupakan analisa potensi usaha yang sesuai dengan kenyataan di lapang

\section{a. Kekuatan dan Peluang}

1. Lokasi perusahaan strategis dekat dengan sumber bahan baku : sangat kuat

- Posisi lokasi dekat dengan pasar dan lahan pertanian produktif

2. SDM (pelaku usaha) yang terampil :

- Mayoritas pelaku usaha rengginang singkong "Produksi Moh. Sunaryo" masing-masing sudah memiliki keterampilan dalam mengolah rengginnag singkong, akan tetapi pengetahuan untuk mengelola manajemen usaha masih sangat minim.

3. Penggunaan bibit yang unggul (Singkong):

- Pemilihan bibit sebelum melakukan penanaman dilakukan secara teliti dan benar-benar dipilih yang produktif, agat kualitas dari rengginang singkong bisa terjaga.

4. Adanya lembaga yang menawarkan modal:

- Usaha Rengginang Singkong "Produksi Moh. Sunaryo" mampu mendapatkan modal dari bank dan pernah mendapatkan bantuan modal berupa alat dari DISPERINDAG

5. Menjadi sentra andalan rengginang singkong :

- Tidak ada wilayah atau home industry rengginang singkong lain yang benar- benar menggeluti dan menekuni usaha rengginang singkong ini. Karena dipandang hasilnya tidak seberapa besar.

6. Segmentasi pasar yang mencolok:

- berpeluang mendapatkan banyak keuntungan, kerena permintaan pasar yang tinggi serta segmentasi pasar yang mencolok. Karena rengginang singkong ini bisa dikonsumsi oleh semua kalangan.

7. Hampir tidak ada pesaing :

- Dikatakan tidak ada pesaing karena dari dua usaha rengginang singkong di Desa Banasare tersebut selalu menjalin kerja sama yang baik. Jika ada persaingan, mungkin persainagnnya hanya denagn usaha rengginang singkong di luar wilayah atau dengan usaha rengginnag ketan.

8. Harga produk terjangkau :

- Harga rengginang singkong ini sangat terjangkau dan dijamin puas. Karena hanya dengan harga Rp. 10.000, konsumen sudah bisa menikmati 1 bungkus dengan isi 50 biji rengginang singkong yang belum masih mentah.

9. Usaha tersebut legal :

- Usaha tersebut dikatakan legal karena sudah ada izin usaha atau SIUP.

\section{Hambatan Potensi Usaha Rengginang Singkong "Produksi Moh. Sunaryo".}

Adapun hal - hal yang perlu diperhatikan untuk mengatasi atau membenahi hambatan dalam mengembangkan potensi Usaha Rengginang Singkong "Produksi Moh. Sunaryo" yaitu : 
1. Promosi yang sangat minim : promosi harus dilakukan dengan gencar, artinya harus banyak pihakpihak yang ikut andil dalam hal promosi sehingga tidak ada kesulitan dalam memperkenalkan produk rengginang singkong.

2. Jumlah penjualan yang sedikit : penjualan harus dilakukan secara besar-besaran dengan memperbaiki kualitas produk rengginang singkong dan berani mengambil resiko pasar.

3. Sarana dan prasarana yang terbatas : harus mengupayakan untuk memenuhi kebutuhan sarana dan prasarana yang sangat diperlukan dalam menunjang keberlangsungan produksi rengginang singkong.

4. Sistem ijon yang melekat pada petani : sistem ijon yang sudah menjadi kebiasaan petani harus dirubah untuk menghindari kerugian akibat menjual singkong sebelum panen dan tidak adanya inovasi produk.

5. Adanya anomali atau perubahan iklim : perubahan iklim yang tidak menentu harus segera ditangani menggunakan teknologi tepat guna, agar tanaman singkong tidak mudah terserang penyakit sehingga dapat merusak kualitas singkong.

\section{Indikator Capaian Potensi Usaha Rengginang Singkong "Produksi Moh. Sunaryo" Desa Banasare.}

Adapun indikator capaian yang menunjukkan bahwa Usaha Rengginang Singkong "Produksi Moh. Sunaryo" berpotensi yaitu apabila usaha tersebut telah mampu memenuhi dua aspek yaitu mempertahankan ketersediaan bahan baku rengginang singkong dan kualitas rengginang yang tinggi dengan adanya sentuhan teknologi yang sangat menunjang keberlangsungan produksi. Sehingga apabila indikator tersebut telah dicapai maka usaha tersebut dikatakan berpotensi. Berdasarkan hasil penelitian, usaha rengginang singkong Desa Banasare belum mampu memenuhi semua indikator yang harus dicapai. Akan tetapi, dengan peluang dan kekuatan yang baik, maka usaha tersebut harus dilanjutkan dengan upaya untuk memenuhi indikator kedua, yaitu indikator teknologi yang akan menunjang kualitas produk. Dengan demikian, usaha tersebut dapat dinilai berpotensi dan akan berkembang.

\section{Preferensi Konsumen Rengginang Singkong "Produksi Moh. Sunaryo".}

Preferensi konsumen atau tanggapannya dengan mengonsumsi rengginang singkong "Produksi Moh. Sunaryo" merasa puas. Karena dengan harga yang terjangkau konsumen sudah bisa merasakan nikmatnya rengginang singkong tersebut. Akan tetapi, konsumen menginginkan bahwa perlu adanya pengembangan dari usaha tersebut agar lambat laun bisa lebih maju dan besar. Kurangnya tenaga kerja dan inovasi produk akan menghambat pemasaran yang harus digalakkan oleh usaha tersebut.

\section{KESIMPULAN}

Berdasarkan hasil kegiatan praktik kerja lapang dengan permasalahan kajian potensi dan strategi pengembangan Usaha Rengginang Singkong "Produksi Moh. 
Sunaryo" di Desa Banasare Kecamatan Rubaru Kabupaten Sumenep. Dapat disimpulkan bahwa :

1. Potensi Usaha Rengginang Singkong "Produksi Moh. Sunaryo", berdasarkan ketersediaan bahan baku dapat dinilai bagus.

2. Berdasarkan hasil analisis preferensi konsumen terkait dengan kualitas produk rengginang singkong hasil produksi Usaha Rengginang Singkong "Produksi Moh. Sunaryo" di Desa Banasare disukai konsumen.

\section{DAFTAR PUSTAKA}

Bambang, 2004. Aneka Produk Olahan Ubi

Kayu. Aneka Ilmu. Semarang

BPS Kecamatan Rubaru tahun 2018

Dumasari, 2014. Strategi Pengembangan Usaha Bisnis Pangan Lokal Olahan Ubi Kayu di Kabupaten Banyumas. AGRITECH. Vol. XVI. No.2 : 129 - 138

Fauziyah, 2016. Kelayakan Finansial dan Nilai Tambah Pengolahan Rengginang Ubi di Barito Koala Kalimantan Selatan. Penelitian Pertanian Tanaman Pangan.Vol 2. No. $2: 129-136$

Husen , 2014. Kajian Pengembangan Industri Kecil Berbasis Ubi kayu Di Desa Negara Bumi, Kecamatan Sungkai Tengah, Kabupaten Lampung Utara. Skripsi. Fakultas Pertanian. Universitas Lampung. Bandar Lampung

Jayadi, 2018. "Programa Penyuluhan Wilayah Binaan Desa Banasare Kecamatan Rubaru". BPP Rubaru : Sumenep

Parmawati, S. 2011 Analisis Usaha Industri Rengginang Singkong Skala Rumah Tangga. Skripsi. Fakultas Pertanian. Universitas Sebelas Maret. Surakarta
Samsul, 2018. "Profil dan Potensi Kecamatan Rubaru". BPP Rubaru Sumenep

Saptariana ,2013. Peningkatan Kualitas Produksi Rengginang Singkong Menggunakan Teknologi Pengering Buatan. Skripsi. Universitas Negeri Semarang

Sugiman, 2018. Interview. Tentang "Potensi Lahan Pertanian Desa Banasare Kecamatan Rubaru Kabupaten Sumenep".

Yaya, 2018. Interview. Tentang Usaha Rengginang Singkong "Moh Sunaryo" Desa Banasare Kecamatan Rubaru Kabupaten Sumenep. 